\title{
The Relationship between Information Asymmetry and Stock Return in the Presence of Accounting Conservatism
}

\author{
Mohammed M. Yassin ${ }^{1}$, Haitham Y. Ali ${ }^{2} \&$ Madher E. Hamdallah ${ }^{1}$ \\ ${ }^{1}$ Al-Zaytoonah University of Jordan, Jordan \\ ${ }^{2}$ Petra University, Jordan \\ Correspondence: Mohammed M. Yassin, Al-Zaytoonah University of Jordan, Jordan. E-mail: \\ mmmy1974@yahoo.com \\ Received: March 10, 2015 \\ Accepted: April 8, $2015 \quad$ Online Published: April 20, 2015 \\ doi:10.5539/ijbm.v10n5p126 \\ URL: http://dx.doi.org/10.5539/ijbm.v10n5p126
}

\begin{abstract}
This study aimed to test the effect of information asymmetry on the stock return in the presence of accounting conservatism in industrial companies listed in Amman Stock Exchange (ASE) in the period from 2006 to 2012. The study found that investors who have private information can benefit from that through achieving outstanding returns, which means that information asymmetry affects the stock return positively, but when taking into consideration the conservative accounting policies practiced by management, this effect was faded.
\end{abstract}

Keywords: information asymmetry, accounting conservatism, stock return, bid-ask spread, Amman Stock Exchange (ASE)

\section{Introduction}

The management owns the opportunity to control what information should be displayed, it is able to withhold or distort some information, and hence the information disclosed in financial statements could not reflect the real situation of the entity, and the management is the only party that has real information about it, and this so-called Information Asymmetry, which arises when a party has private information about the entity's value, while other parties only possess general information published and available to all.

In general, informed parties seek to take advantage of their information directly or indirectly in the financial market, and this is at the expense of the uninformed parties, these attempts of informed parties to get benefit from private information will increase the agency cost (Jensen \& Meckling, 1976) which will decrease the present value of the expected cash flows. The management may act based on information it has, in a way that maximizes its benefit on the expense of the uninformed parties. For example, management could choose to disclose higher profits in order to maximize its compensation. Management may also make decisions that increase profits in the short term at the expense of the long term profits such as choosing the lower salary and efficiency employees, or lowering the $R \& D$ expenses. The uninformed parties recognize the presence of information asymmetry circumstance which is not suitable for them; this will increase the risk of investing in such entity, which will be reflected in requiring higher returns.

In other words, information asymmetry will reduce the stock price for two reasons: First, the higher the agency cost, the lower the present value of expected cash flows. Second, the higher the investment risk, the higher the required return, where the financial market responds to the higher agency cost with lowering the stock price, as a reaction to this and to maintain their interests, management increases the degree of conservatism in the financial reports, which will give management higher credibility from the investors' viewpoint (uninformed parties), which will lower the agency cost, and increase the stock price (LaFond \& Watts, 2007).

The aim of this study is to investigate the effect of information asymmetry on the stock returns in the presence of accounting conservatism and other factors affecting the stock return such as the stock return for the previous day, trading volume of shares, and risk. The sample of this study consists of industrial companies listed in Amman Stock Exchange for the period from 2006 to 2012.

\section{Literature Review \& Hypotheses Development}

In recent decades, a large number of researchers have tested the factors that affect the stock returns, including 
risk and trading volume. These studies mainly return to (Rogalski, 1978), (Figlewski, 1981), and (Cornell, 1981), these studies sought to examine the relationship between these variables, which found that there is a positive relationship between risk, trading volume, and stock return. Also (Wang et al., 2005) tested the relationship between the behavior of market stock returns, volatility of returns (Risk), and trading volume. The results confirmed that the volume of trading, which was used as a measure of information access, has a positive effect on the stock return. (Battilossi \& Houpt, 2006) aimed to test the existence of serial correlation in the values of stock return, and through the analysis the results was positive, which means that the stock return is affected by the previous day's stock return.

Information asymmetry is known as having a party for more information than other parties, and this happens when the seller has more information than the buyer or vice versa, this situation is not preferable because one party can take advantage of the information available to him to achieve certain benefits on the expense of other parties who have less information. In some cases, information asymmetry occurs when one party exploits some loopholes in agreements or contracts, while other parties can not so (Aboody \& Lev, 2000).

Many researchers studied the relationship between information asymmetry and stock returns, and most of them found a positive relationship exists. A study for (Easley \& O'Hara, 2004) found that the portfolio consisting of shares purchased with high information asymmetry gains abnormal profits, researchers have interpreted these results as information asymmetry distinguishes dealers to a team that has more information and the general dealers who have less information. And as all dealers seek optimal diversification to minimize risk, only the team which has more information succeed, and this leads to asymmetry in risk and abnormal profits to who has information. Another study performed by (Gul \& Qiu, 2002) aimed to test the relationship between the application of corporate governance and the degree of information asymmetry in developing financial markets. The scale used to measure information asymmetry was built on the idea that investors in their assessment of shares depend not only on the current performance of the business, but also on the future expected performance, and this dependence increases by the availability of transparency and uniformity of information, in other words, the higher the stock prices to predict the future accounting performance, the lower the information asymmetry. The study found that entities in countries that apply the corporate governance characterized by a lesser degree of information asymmetry, and entities in countries with developed markets also characterized by a lesser degree of information asymmetry. While (Levi \& Zhang, 2008) study confirmed that increasing information asymmetry leads to increased expected market return, and that change stock return can be written as a function of information asymmetry and interpreted through it.

Regarding the relationship between accounting conservatism and information asymmetry, (LaFond \& Watts, 2007) assumed that the existence of information asymmetry between investors will lead to the emergence of accounting conservatism in financial statements, due to the fact that accounting conservatism reduces the ability of management to manipulate accounting numbers, which will lead to a reduction of information asymmetry, and also may lead to an increase in the market value of the entity. The results showed that information asymmetry leads to an increase in accounting conservatism in financial statements, taking into consideration the stability of other factors that increase conservatism. Also, the results showed that information asymmetry causes accounting conservatism, and not vice versa, and this result contradicts the opinion of the FASB which believes that accounting conservatism causes information asymmetry between investors. Chi and Wang (2008) study reinforced the previous findings of (LaFond \& Watts, 2007) and concluded that information asymmetry is not only positively correlated with accounting conservatism, but also causes it.

To achieve the objectives of the study, the hypotheses can be formulated so that to examine the impact of the factors that affect the stock return as a first stage, which are the previous day's stock return, risk, and trading volume, and then enter the information asymmetry variable to the model to examine its impact on the stock return, and in the third stage, accounting conservatism will be added to the model to examine its impact on the relationship. The study hypotheses are as follows:

Ho1: There is no statistical significant effect of the previous day's stock return (Rt-1), risk (Risk), and trading volume $(V)$ on the stock return $\left(R_{t}\right)$.

Ho2: There is no statistical significant effect for information asymmetry $(A S Y)$ on the stock return $\left(R_{t}\right)$ in the presence of the previous day's stock return (Rt-1), risk (Risk), and trading volume (V).

Ho3: There is no statistical significant effect for information asymmetry (ASY) on the stock return $\left(R_{t}\right)$ in the presence of the previous day's stock return (Rt-1), risk (Risk), trading volume (V), and accounting conservatism (CON). 


\section{Method}

\subsection{The Study Sample}

The sample of this study consists of industrial companies listed in Amman Stock Exchange (ASE) for the period between 2006 and 2012. The companies included in this study should be characterized by certain conditions such as:

- The company should be listed in ASE before 1/1/2005 in order to ensure that the price of the stock is stable at certain levels.

- The companies selected had not been subjected to liquidation, merger, or restructuring during the period of the study.

- The number of trading days of the share is at least 180 days per year, to get rid of the (Thin Trading) problem.

Based on the previous conditions, the study reached to a sample of (26) companies, and the total observations included in the analysis was (30604) panel data, because the observations were on a daily basis over seven years.

\subsection{Model \& Variables}

For the purpose of testing hypotheses, formulas (1,2, and 3) will be used, where formula (1) tests the impact of the previous day's stock return, risk, and trading volume on the stock return, while formula (2) included information asymmetry as an additional independent variable to the variables in formula (1), and formula (3) measures the same effect of variables in formula (2) in the presence of accounting conservatism as an additional control variable to the relationship.

$$
\begin{aligned}
& R_{i, t}=\alpha_{i, t}+\beta_{1} R_{i, t-1}+\beta_{2} \text { Risk }_{i, t}+\beta_{3} V_{i, t}+\varepsilon_{i, t} \\
& R_{i, t}=\alpha_{i, t}+\beta_{1} R_{i, t-1}+\beta_{2} \text { Risk }_{i, t}+\beta_{3} V_{i, t}+\beta_{4} A S Y_{i, t}+\varepsilon_{i, t} \\
& R_{i, t}=\alpha_{i, t}+\beta_{1} R_{i, t-1}+\beta_{2} \operatorname{Risk}_{i, t}+\beta_{3} V_{i, t}+\beta_{4} A S Y_{i, t}+\beta_{5} \operatorname{CON}_{i, t}+\varepsilon_{i, t}
\end{aligned}
$$

Where $R_{i, t}$ is the stock return for company $\mathrm{i}$ in the period $\mathrm{t}, R_{i, t-1}$ is the stock return for company $\mathrm{i}$ in the previous period $\mathrm{t}-1,{ }^{\text {Ris }} k_{i, t}$ is the stock risk for company $\mathrm{i}$ in the period $\mathrm{t}, V_{i t}$ is the trading volume for company $\mathrm{i}$ in the period t, $A S Y_{i, t}$ is the information asymmetry measure for company $\mathrm{i}$ in the period t, and ${ }^{C O N_{i, t}}$ is the accounting conservatism measure for company $i$ in the period $t$.

A number of researchers such as (Karpoff, 1987); (Brock \& Lebaron, 1996); (Lee \& Rui, 2002); (Mestel, Gurgul, \& Majsdoz, 2003) interpret the change in stock return through analyzing its relationship with previous day's stock return, risk, and trading volume, and used several measures. This study will use the difference between current price and previous price plus dividends, divided by previous stock price. The stock risk will be measured using the measure used in (Floros, 2009) by dividing the difference between highest and lowest on the daily average stock price, and the traditional relationship between risk and return indicates a positive relationship. The trading volume will be measured by calculating the natural logarithm of the daily trading volume, which is supposed to be a positive influence.

According to Jack Treynor Theory, information asymmetry affects the stock price positively. He suggested that trading operations; which are based on information affect the difference between the prices of sale orders and purchase orders (Bagehot, 1971), the more the private information, the more the price difference between sale orders and purchase orders or the so-called (Bid-Ask Spread), and this leads to increase returns of informed investors, while decrease the returns of uninformed investors. Also (Easley \& O'Hara, 2004) developed a theoretical model confirms that the stock returns around which there is more private information (ie whenever more information asymmetry) are usually larger. As in previous studies, this study will measure information asymmetry by dividing the price spread (The difference between the best bid and the best ask) on the average daily stock price.

(Healy et al., 1999), ( Leuz \& Verrecchia, 2000) believed the existence of a relationship between the accounting disclosure and information asymmetry, where the accounting disclosure and the quality of the accounting information reduces the chances of getting information from external sources, and this will reduce information asymmetry. And as the conservative accounting policies increase the quality of disclosure and the transparency of accounting reports (see for example Watts, 2003a; Ball \& Shivakumar, 2005), it is supposed that accounting 
conservatism will automatically reduce information asymmetry between investors, because this will produce good earnings quality. This study will use market-to-book (M/B) ratio to measure the accounting conservatism according to (Roychowdhury \& Watts, 2006), as the high M/B indicates the existence of conservative accounting practices, which led to a reduction in the book value of the share.

\subsection{Statistical Method}

A pooled data regression was run to test the effect of information asymmetry on stock return in the presence of accounting conservatism and other variables that affect the stock return, such as the previous day's stock return, risk, and trading volume, this test was implemented using (Eviews 4.0). The pooled data regression is used when the data collected is in the form of time series (several periods) and sectoral (several companies) (ie Time series and cross sectional), specifically we will use Seemingly Unrelated Regression (SUR), which is used when the data is composed from long time series (such as daily observations) and small number of sectors (Wooldridge, 2002).

\subsection{Descriptive Statistics}

Table 1 shows the descriptive statistics of the study variables. The mean of the stock return was approximately 0.001 , and in spite of the low figure but it reflects the fact that on average the positive stock returns exceeds the negative ones, while the standard deviation was $3 \%$, this figure was high if we take into consideration the low average stock return, where the standard deviation is equivalent to almost 30 times the average stock return, and this points to a large disparity between the stock returns as well as to the high risk of investing in these companies in general. Also the statistics related to the previous day's stock return do not significantly differ from the stock return statistics. While the average trading volume (logarithm) was about 4.42 which is equivalent to JD26,303 and a standard deviation of 0.95 which is equivalent to JD9, and this indicates that the average daily trading volume reflects stability in trading. The average daily stock risk amounted about 3\% with standard deviation of $2 \%$, and these values generally indicates low risk in the industrial sector stock trading. While the average daily information asymmetry as a percentage of the price was $6 \%$ and a standard deviation of $19 \%$, these values show an existence of information asymmetry among investors, there are different levels and variations in information among investors as evidenced by the standard deviation. Finally, the average M/B ratio (accounting conservatism measure) was 1.73 times and a standard deviation of 1.28 times, these values reflect large practices of accounting conservatism, because the market values of stocks was equivalent to 1.73 times their book values. Skewness and kurtosis statistics show that the stock return does not have a normal distribution, these results was evidenced by Jarque-Bera statistic.

Table 1. Descriptive statistics of variables

\begin{tabular}{lllllll}
\hline & Rt & Rt-1 & Vi & RISK & ASY & CON \\
\hline Mean & 0.00103 & 0.00101 & 4.42 & 0.03 & 0.06 & 1.73 \\
Std. Dev. & 0.03 & 0.03 & 0.95 & 0.02 & 0.19 & 1.28 \\
Skewness & 58.07 & 59.06 & -0.41 & 1.06 & 4.62 & 2.87 \\
Kurtosis & 7373.44 & 7371.71 & 3.26 & 4.28 & 18.42 & 14.08 \\
Jarque-Bera & 8333000 & 8333000 & 874.96 & 9432.81 & 554741.92 & 199987.2 \\
Probability & 0.00000 & 0.000000 & 0.000000 & 0.000000 & 0.000000 & 0.000000 \\
Observations & 30604 & 30604 & 30604 & 30604 & 30604 & 30604 \\
Cross sections & 26 & 26 & 26 & 26 & 26 & 26 \\
\hline
\end{tabular}

Where Rt is the stock return, Rt-1 is the previous day's stock return, Vi is the trading volume, RISK is the stock risk, ASY is the information asymmetry measure, $\mathrm{CON}$ is the accounting conservatism measure.

\section{Results Discussion}

Formula 1 tests the effect of previous day's stock return, risk, and trading volume on the stock return, this formula is the basic model that other formulas depend on.

Table 2 shows the results of the regression model of formula (1), we can note that previous day's stock return, risk, and trading volume have significantly positive effect on the stock return at $1 \%$ significant level. All these results are in line with the previous research results which used the same model. The null hypothesis will be rejected which indicates that there is no statistical significant effect of the previous day's stock return (Rt-1), risk (Risk), and trading volume $(\mathrm{V})$ on the stock return $(\mathrm{Rt})$. 
Adjusted R-squared was $17.32 \%$, which means that independent variables interpret $17.32 \%$ of the change in the stock return. Durbin-Watson statistic shows a lack of autocorrelation in data.

Table 2. Regression results for formula (1)

\begin{tabular}{llll}
\multicolumn{4}{c}{$R_{i, t}=\alpha_{i, t}+\beta_{1} R_{i, t-1}+\beta_{2} R_{i s k}$} \\
\hline$\underline{\text { Variable }}$ & $\underline{\text { Coefficient }}$ & $\underline{\text { t-Statistic }}$ & $\underline{\text { Prob. }}$ \\
\hline $\boldsymbol{A}$ & -0.01712 & -18.73115 & 0.0000 \\
$\boldsymbol{\beta}_{1}$ & 0.06986 & 11.89715 & 0.0000 \\
$\boldsymbol{\beta}_{2}$ & 0.13134 & 13.09085 & 0.0000 \\
$\boldsymbol{\beta}_{3}$ & 0.00624 & 16.48240 & 0.0000 \\
R-squared & & 0.1946 & \\
Adjusted R-squared & & 0.1732 & \\
Durbin-Watson stat & & 2.1701 & \\
Sample & $1 / 1 / 2006-31 / 12 / 2012$ \\
Number of cross-sections & & 26 & \\
Total panel observations: & & 30604 & \\
\hline
\end{tabular}

Formula 2 tests the effect of previous day's stock return, risk, trading volume, and information asymmetry on the stock return.

Table 3 shows the regression results of this model; through this table we can note that previous day's stock return, risk, and trading volume have significantly positive effect on the stock return at $1 \%$ significant level. Also information asymmetry, the new independent variable that was added to the formula has a positive significant effect on the stock return, which means that an increase in information asymmetry between investors leads to an increase in the stock return. All these results are in line with previous studies, also these results agree with Jack Treynor theory, which suggested that the trading operations which are based on information affect the difference between bid and ask prices (Bagehot, 1971), since the more private information, the greater the bid-ask spread, which leads to an increase in stock return. Also these results agree with (Easley \& O'Hara, 2004) which concluded that an increase in information asymmetry leads to an increase in stock return. Based on the above, the null hypothesis will be rejected, which indicates that there is no statistical significant effect for information asymmetry (ASY) on the stock return (Rt) in the presence of the previous day's stock return ( $\left.\mathrm{R}_{\mathrm{t}-1}\right)$, risk (Risk), and trading volume $(\mathrm{V})$.

Table 3. Regression results for formula (2)

\begin{tabular}{|c|c|c|c|}
\hline$\underline{\text { Variable }}$ & $\underline{\text { Coefficient }}$ & $\underline{\text { t-Statistic }}$ & Prob. \\
\hline $\boldsymbol{A}$ & -0.01523 & -19.1542 & 0.0000 \\
\hline $\boldsymbol{\beta}_{1}$ & 0.08245 & 12.2145 & 0.0000 \\
\hline$\beta_{2}$ & 0.11998 & 13.3377 & 0.0000 \\
\hline $\boldsymbol{\beta}_{3}$ & 0.00465 & 17.1154 & 0.0000 \\
\hline$B_{4}$ & 0.00319 & 2.9881 & 0.0019 \\
\hline R-squared & & 0.2124 & \\
\hline Adjusted R-squared & & 0.1983 & \\
\hline Durbin-Watson stat & & 2.0304 & \\
\hline Sample & & $1 / 1 / 2006-$ & \\
\hline Number of cross-sections & & 26 & \\
\hline Total panel observations: & & 30604 & \\
\hline
\end{tabular}

The adjusted R-squared has risen in this model to $19.8 \%$ compared with the value of the previous model, which reflects the importance of information asymmetry variable that was added to the model.

Formula (3) tests the effect of previous day's stock return, risk, trading volume, information asymmetry, in the 
presence of accounting conservatism on the stock return. Table 4 shows the regression results of formula (3) which contained an additional control variable, namely accounting conservatism. Through this table, we can note that previous day's stock return, risk, and trading volume have significantly positive effect on the stock return at $1 \%$ significant level, and these results agree with the results of the previous two models.

Information asymmetry variable has become non-statistically significant, suggesting that entering the accounting conservatism to the model has cancelled the effect of information asymmetry variable on the stock return. This finding suggests that accounting conservatism practices affect information asymmetry and lead to reducing its importance in influencing stock return.

Table 4. Regression results for formula (3)

\begin{tabular}{llll}
$R_{i, t}=\alpha_{i, t}+\beta_{1} R_{i, t-1}+\beta_{2} R_{i s k}$ & $+\beta_{3} V_{i, t}+\beta_{4} A S Y_{i, t}+\beta_{5} C O N$ & \\
\hline Variable & $\underline{\text { Coefficient }}$ & $\underline{\text { t-Statistic }}$ & $\underline{\text { Prob. }}$ \\
\hline $\boldsymbol{A}$ & -0.022145 & -21.3124 & 0.0000 \\
$\boldsymbol{\beta}_{1}$ & 0.039946 & 8.88795 & 0.0000 \\
$\boldsymbol{\beta}_{2}$ & 0.087795 & 13.0045 & 0.0000 \\
$\boldsymbol{\beta}_{3}$ & 0.003415 & 17.3215 & 0.0000 \\
$\boldsymbol{\beta}_{4}$ & 0.000578 & 0.89946 & 0.2946 \\
$\boldsymbol{\beta}_{5}$ & -0.000228 & -1.73458 & 0.1308 \\
R-squared & & 0.1978 & \\
Adjusted R-squared & & 0.1731 & \\
Durbin-Watson stat & & 2.019672 & \\
Sample & $1 / 1 / 2006-31 / 12 / 2012$ \\
Number of cross-sections & 26 \\
Total panel observations: & 30604 \\
\hline
\end{tabular}

Accounting conservatism did not have a significant impact on the stock return, in the sense that conservative accounting policies does not affect directly the stock return, but it is limited by impacting information asymmetry, which is considered as one of the important factors affecting the stock return. And so the null hypothesis will be accepted, indicating that there is no statistical significant effect for information asymmetry (ASY) on the stock return $\left(\mathrm{R}_{\mathrm{t}}\right)$ in the presence of the previous day's stock return $\left(\mathrm{R}_{\mathrm{t}-1}\right)$, risk (Risk), trading volume $(\mathrm{V})$, and accounting conservatism $(\mathrm{CON})$.

Adjusted R-squared has declined to $17.31 \%$ compared with the results of formula (2), this decline reflects the fading effect of information asymmetry on stock return because of entering the accounting conservatism to the formula.

\section{Conclusion}

This study aimed to test the effect of information asymmetry on the stock return in the presence of accounting conservatism. The study found that investors who have private information can benefit from that through achieving outstanding returns, which means that information asymmetry affects the stock return positively, but when taking into consideration the conservative accounting policies practiced by management, this effect was faded. Further studies are recommended in the same field, by using different measures of conservatism to assert or repeal the results of this study. Also there is a need to improve the level of financial disclosure, since it is known that information asymmetry appears due to weak system of financial disclosure and delay of information.

\section{References}

Aboody, D., \& Lev, B. (2000). Information Asymmetry, R\&D, and Insider Gains. The Journal of Finance, 55, 2747-2766. http://dx.doi.org/10.1111/0022-1082.00305

Bagehot, W. P., \& Treynor, J. (1971). The only game in town. Financial Analysts Journal, 27, 12-17. http://dx.doi.org/10.2469/faj.v27.n2.12

Ball, R., \& Shivakumar, L. (2005). Earnings Quality in U.K. private firms. Journal of Accounting and Economics, 39. http://dx.doi.org/10.2139/ssrn.335420

Battilossi, S., \& Houpt, S. (2006). Risk, Return and Volume in an Emerging Stock Market. Universidad Carlos III de Madrid. 
Beaver, W., \& Ryan, S. (nd.). Conditional and Unconditional Conservatism: Concepts and Modeling. Review of Accounting Studies, 10(2-3). http://dx.doi.org/10.1007/s11142-005-1532-6

Bharath, S., Pasquariello, P., \& Wu, G., (2008). Does Asymmetric Information Drive Capital Structure Decisions? The Review of Financial Studies, 1-33. http://dx.doi.org/10.1093/rfs/hhn076

Bodie, Z., Kane, A., \& Marcus, A. (2008). Essentials of Investments (7th ed.). New York: McGraw-Hill/Irwin.

Brock, W. A., \& Lebaron, B. D. (1996). A dynamic structural model for stock return volatility and trading volume. The Review of Economics and Statistics, 78(1), 94-110. http://dx.doi.org/10.2307/2109850

Brown, S., \& Hillegeist, S. A. (2007). How Disclosure Quality Affects the Level of Information Asymmetry. University of Maryland-Department of Accounting \& Information Assurance,.http://dx.doi.org/10.1007/s11142-007-9032-5

Chi, W. C., \& Wang, C. C. (2008). Information Asymmetry and Accounting Conservatism: Evidence from Taiwan. Department of Accounting, National Taipei University.

Cornell, B. (1981). The Relationship Between Volume and Price Variability in Futures Markets. Journal of Futures Markets, 1(Fall), 303-316. http://dx.doi.org/10.1002/fut.3990010303

Easley, D., \& O'Hara, M. (2004) Information and the cost of capital. The Journal of Finance, 59, 1553-1583. http://dx.doi.org/10.1111/j.1540-6261.2004.00672.x

Figlewski, S. (1981). Futures Trading and Volatility in the GNMA Market. Journal of Finance, 36, 445-456. http://dx.doi.org/10.1111/j.1540-6261.1981.tb00461.x

Floros, C. (2009). Modeling Volatility Using High, Low, Open and Closing Prices: Evidence from Four S\&P Indices. International Research Journal of Finance and Economics, 28.

Glaser, M., \& Weber, M. (2008). Which Past Return Affect Trading Volume?

Gul, F. A., \& Han, Q. (2002). Legal Protection, Corporate Governance and Information Asymmetry in Emerging Financial Markets. Working Paper. Hong Kong Polytech University. http://dx.doi.org/10.2139/ssrn.298169

Healy, P. M., Hutton, A. P., \& Palepu, K. G. (1999). Stock performance and intermediation changes surrounding sustained increases in disclosure. Contemporary Accounting Research, 16, 485-520. http://dx.doi.org/10.1111/j.1911-3846.1999.tb00592.x

Jensen, M. C., \& Meckling, W. H. (1976). Theory of the firm: managerial behavior, agency costs \& ownership $\begin{array}{lllll}\text { structure. Journal of } & \text { Financial }\end{array}$ http://dx.doi.org/10.1016/0304-405X(76)90026-X

Karpoff, J. M. (1987). A Relation between Price Changes and Trading Volume: A Survey. Journal of Financial and Quantitative Analysis, 22, 109-126. http://dx.doi.org/10.2307/2330874

LaFond, R., \& Watts R. (2007). The Information Role of Conservatism.

Lee, B. S., \& Rui, O. M. (2002). The dynamic relationship between stock returns and trading volume: Domestic and cross-country evidence. Journal of Banking and Finance, 26(1), 51-78. http://dx.doi.org/10.1016/S0378-4266(00)00173-4

Leuz, C., \& Verrecchia, R. E. (2000). The economic consequences of increased disclosure. Journal of Accounting Research, 38, 91-124. http://dx.doi.org/10.2307/2672910

Levi, S., Zhang, X. J. (2008). Information Asymmetry and the Increase in Expected Stock Returns Before Earnings Announcements.

Mestel, R., Gurgul, H., \& Majdosz, P. (2003). The Empirical Relationship between stock returns, return volatility and trading volume on the Austrian stock market. University of Graz, Institute of Banking and Finance, Research Paper.

Rogalski, R. J. (1978). The Dependence of Prices and Volume. Review of Economics and Statistics, 60, 268-274. http://dx.doi.org/10.2307/1924980

Roychowdhury, S., \& Watts, R. (n.d.). Asymmetric Timeliness of Earnings, Market-to-Book and Conservatism in Financial Reporting.

Wang, P., \& Aying, L. (2005). Stock return volatility and trading volume: Evidence from the Chinese stock market. J. Chin. Econ. Bus. Stud., 3(1), 39-54. http://dx.doi.org/10.1080/14765280500040518 
Watts, R. (2003). Conservatism in accounting-part 1: Explanations and Implications. Accounting Horizons, 17, 207-221. http://dx.doi.org/10.2139/ssrn.371820

Wittenberg-Moerman, R. (2008). The role of information asymmetry and financial reporting quality in debt trading: Evidence from the secondary loan market. University of Chicago Graduate School of Business. Retrieved from http://ssrn.com/abstract $=876867$

Wittenberg-Moerman, R. (2009). The Impact of Information Asymmetry on Debt Pricing and Maturity. Retrieved from http://ssrn.com/abstract $=1152863$

Wooldridge, J. (2002). Econometric Analysis of Cross Section and Panel Data. MIT.

\section{Copyrights}

Copyright for this article is retained by the author(s), with first publication rights granted to the journal.

This is an open-access article distributed under the terms and conditions of the Creative Commons Attribution license (http://creativecommons.org/licenses/by/3.0/). 